\title{
Electrochemistry: connector of sciences
}

\author{
Uwe Schröder ${ }^{1}$ (D)
}

Received: 20 May 2020 / Revised: 20 May 2020 / Accepted: 22 May 2020 / Published online: 29 May 2020

(C) The Author(s) 2020

Electrochemistry is a niche subject. We get this impression when looking into the curricula of chemistry courses - at least at German universities. They contain electrochemistry usually as a minor aspect of physical or general chemistry in undergraduate courses-mostly confined to electrolyte concepts and electrochemical equilibria; advanced electrochemistry courses are scarce and are generally tied to graduate programs at departments with active electrochemical research. Thereby, chairs with an explicit electrochemistry denomination are the exception, and the majority of active groups and chairs operate under the flag of physical, analytical, technical, inorganic, or organic chemistry - or related engineering subjects. The scientific output of the electrochemical community does not reflect this apparent niche existence. Thus, a SciVal analysis (from May 12, 2020) for the years 2014-2019 shows that the international publication output in electrochemistry of 74,320 publications is more than half as high as the number of publications in inorganic chemistry $(134,165)$, one of the main subjects in chemistry. This underlines the creativeness of a vital community.

It is obvious and beyond discussion of this article that electrochemistry has become a core element for the research and development in regenerative energy conversion and storage. This trend is reflected in the strong increase in the relative share of fuel cell and battery-related publications over the past 20 years within the electrochemistry field (See Fig. 1). The trend underlines the effects of a focused and strongly

Uwe Schröder

uwe.schroeder@tu-braunschweig.de

1 Institute of Environmental and Sustainable Chemistry, Technische Universität Braunschweig, Hagenring 30,

38106 Braunschweig, Germany increased research funding in this area, which has a significant impact on the publication activity. Looking at fuel cells, the growth trends seem enduring, although the focus of research funding has recently been shifted towards batteries.

The current political and social-economic efforts to realize electro-mobility have pushed electrochemistry forward - and into the public and general scientific awareness. This is a unique chance to sustainably strengthen the electrochemical research landscape, e.g., by establishing new research groups and university chairs. Yet, in this development, the rich diversity of electrochemistry should not be sacrificed. Electrochemistry is much broader than battery research. It bridges so many disciplines - from physical chemistry, organic, and inorganic chemistry, as well as green chemistry, to even biology and biochemistry, making electrochemistry an inherently interfacial science, rather than a stand-alone discipline. This explains why we find electrochemical research in so different science and engineering departments - and why electrochemistry should always have its home in these disciplines. I would even go as far as to say that the self-conception of electrochemistry should always be to serve as a connector of sciences. I see this inherent connection in my core research field - microbial electrochemistry and technology. Here, electrochemistry links biology, biochemistry, physical chemistry, materials science, biotechnology, and environmental technology - and even biogeochemistry. The resulting multidisciplinarity creates a fascination that I have missed for a long time in electrochemistry and that attracts many new, young researchers.

Yet, to exploit the full potential of a multifaceted electrochemistry, a huge gap needs to be closed - the deficient and often rudimentary electrochemical education. Thus, as much as electrochemistry connects to so many disciplines is part of these disciplines, it should also become part of their education. 


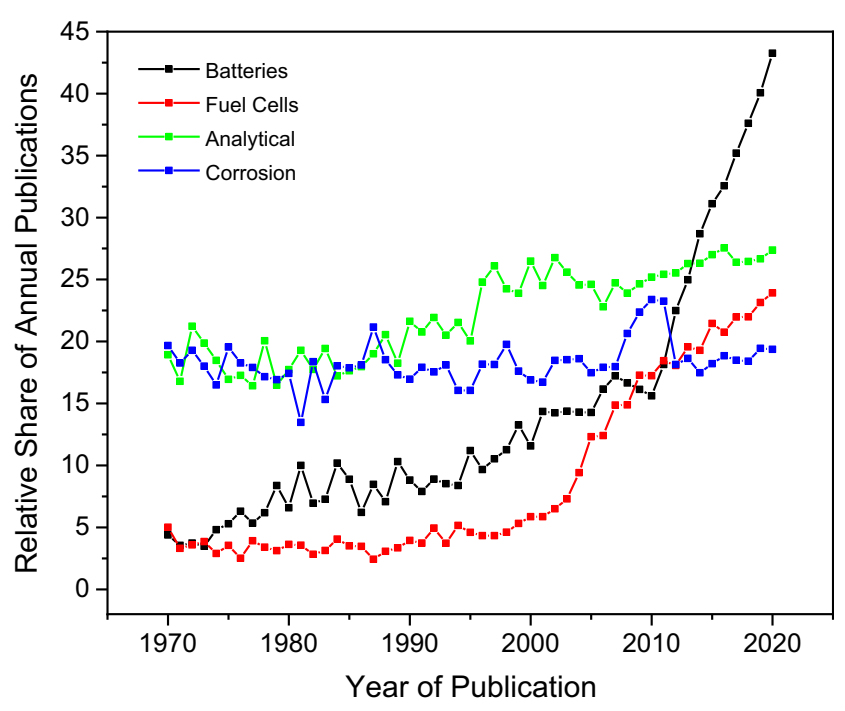

Fig. 1 Scopus analysis (from May 12, 2020), based on the main keyword "electrochemical". The total number of publication hits for the years 1970-2020 was 524,538. The depicted publication trends are based on a subsequent search refinement using the depicted search item "battery," "fuel cell," "corrosion," and "analytical" and show the relative share of the individual item in relation to the total number of publication for each year. (Please note that this is not a comprehensive analysis but a simplified approximation of the publication development, based on a simple keyword analysis.)
In this context, a new generation of electrochemistry textbooks is needed that leave the ivory tower of an often abstract electrochemistry in order to connect the fundamentals of electrochemistry with a profound introduction into the electrochemical methods that goes beyond the often repeated description of standard cases, such as cyclic voltammetry under diffusion-controlled conditions. This should include a comprehensive and hands-on description of advanced and applied electrochemical methods and their use to address different questions and systems (e.g., from voltammetry performed in three-electrode cells to c-rate experiments at assembled batteries) - information that is so far scattered in electrochemical literature.

Funding Information Open Access funding provided by Projekt DEAL.

Open Access This article is licensed under a Creative Commons Attribution 4.0 International License, which permits use, sharing, adaptation, distribution and reproduction in any medium or format, as long as you give appropriate credit to the original author(s) and the source, provide a link to the Creative Commons licence, and indicate if changes were made. The images or other third party material in this article are included in the article's Creative Commons licence, unless indicated otherwise in a credit line to the material. If material is not included in the article's Creative Commons licence and your intended use is not permitted by statutory regulation or exceeds the permitted use, you will need to obtain permission directly from the copyright holder. To view a copy of this licence, visit http://creativecommons.org/licenses/by/4.0/. 